Article

\title{
Road Expansion and Its Influence on Trail Sustainability in Bhutan
}

\section{Taiichi Ito}

Faculty of Life and Environment, University of Tsukuba, Tsukuba 305-8572, Japan;

E-Mail: ito.taiichi.ft@u.tsukuba.ac.jp; Tel.: +81-29-853-4576; Fax: +81-29-853-4576

Received: 7 October 2011; in revised form: 24 November 2011 / Accepted: 28 November 2011 / Published: 9 December 2011

\begin{abstract}
Bhutan was an inhabited wilderness until 1961, when road construction started after the closure of the Tibetan border. Since then, the road network has expanded from the Indian boarder, often tracing traditional trails. This has accelerated commerce as well as movement of people from India, benefitting both the Bhutanese and foreign tourists. At the same time, dependence on imported automobiles and fossil fuel has risen, and roadless areas have begun to shrink. This brought an inevitable loss of traditional environmental knowledge, such as the care of mules for packing, and reduction in physical and mental health among the Bhutanese. People who lost jobs as horsemen moved into towns to find jobs. Road extension is also a double-edged sword for visitors. It has resulted in shrinking trekking areas and loss of traditional culture, both of which have been sacrificed for easy access. Protected areas often function as fortifications against mechanical civilization. However, protected-area status or its zoning does not guarantee that an area will remain roadless where there is considerable resident population. An analysis in Jigme Dorji National Park showed the gradual retreat of trailheads and increasing dependence on automobiles among residents and trekkers. B. MacKaye, a regional planner in the Eastern United States, proposed using trails as a tool to control such mechanical civilization. His philosophy of regional planning suggests two measures; one is consolidated trailheads as dams, and the other is confinement of roads by levees, consisting of new trails and wilderness belts. According to case studies, the author proposed six options for coexistence of trails with roads.
\end{abstract}

Keywords: Bhutan; inhabited wilderness; roadless area; traditional environmental knowledge; trailhead; trekking 


\section{Introduction}

Visitors to Bhutan often say that the whole country looks like a national park. One reason is the harmonized landscape that includes traditional houses and their residents wearing traditional clothing. The other is the tariff system that was introduced in 1974 when Bhutan started hosting foreign tourists, except those from India. The royalty portion of the tariff resembles an entrance fee to a protected area. Actually, the royalty is spent to support free medical care and free education in isolated communities, which are often located in national parks.

Protected areas in Bhutan (Figure 1), which occupy 51\% of the total land area [1], do not charge entrance fees, partly because there are communities in the parks. In the case of Jigme Dorji National Park, which has a total area of 4,316 square $\mathrm{km}$, a population of 6,000 people lives mainly in Gasa district or the vicinity [2]. Unlike many national parks in developed countries, Gasa residents live in a roadless area.

Figure 1. Protected areas of Bhutan (Courtesy of Phuntsho Thinley).

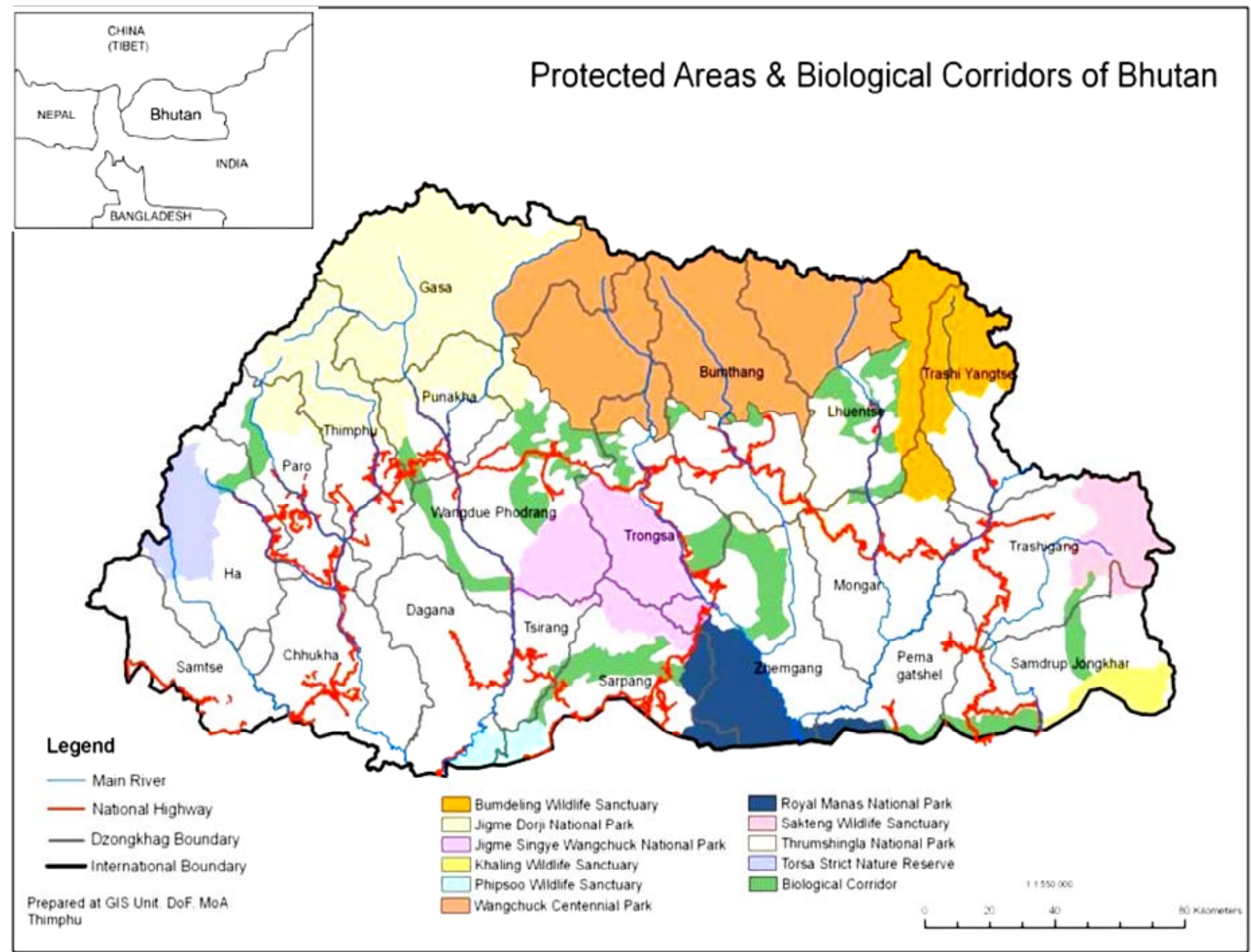

However, expansion of the road system is rapidly changing the landscape as well as the lifestyle of the Bhutanese. Bhutan was a roadless country or inhabited wilderness until 1962, when the first road was constructed from the Indian border town of Phuentsholing to Paro. Now, the road network has 
been expanded to cover all districts, except for Gasa, which is located in the heart of Jigme Dorji National Park.

This paper analyzed the influence of road expansion on trails and their users, such as residents and trekkers, based on documents written in English and Japanese. The current condition of the trails and trailheads was also examined through field surveys conducted during the monsoon seasons of 2008, 2009, 2010 and 2011. Based on these two approaches, sustainable trail use and management are discussed.

\section{Historic Analysis of Trail-to-Road Transitions}

Historic information on the trails and roads in Bhutan is limited because visitors were restricted to royal guests until 1974. The author used documents published by such guests as J. C. White in 1905-1907, B. K. Todd in 1952, S. Nakao in 1958, D. Doig in 1962, and M. Matsuo in 1969. Table 1 shows the routes they used to visit Bhutan. These trails have long trading history, but passes to Tibet are officially closed now. Places they visited are shown in Figure 2.

Table 1. Early visitors and their routes in Bhutan.

\begin{tabular}{|c|c|c|c|}
\hline Year & Months & Explorers & Routes \\
\hline 1905 & March & $\begin{array}{l}\text { J. C. White } \\
\text { Political Officer }\end{array}$ & $\begin{array}{l}\text { Gangtok (Sikkim)-Natu La-Ha-Paro-Thimphu-Punakha- } \\
\text { Tongsa-Thimphu-Lingzhi La-Pangri Dzong (Tibet)-Gangtok }\end{array}$ \\
\hline 1906 & May & & $\begin{array}{l}\text { Gangtok-Gauhati (Assam)-Dewangiri-Trashigong-Tashi } \\
\text { Yangtse-Bodo La-Sela (Tibet)-Gangtok }\end{array}$ \\
\hline 1907 & November & & Gangtok-Pangri Dzong-Tremo La-Drygel Dzong-Phuntsholing \\
\hline 1952 & June- November & $\begin{array}{l}\text { B. K. Todd } \\
\text { Businessman }\end{array}$ & $\begin{array}{l}\text { Kalingpong (Sikkim)-Samti-Sele La-Ha-Paro-Thimphu- } \\
\text { Chubuka Dzong-Phuntsholing-Kalingpong }\end{array}$ \\
\hline 1958 & June-November & $\begin{array}{l}\text { S. Nakao } \\
\text { Esnobotanist }\end{array}$ & $\begin{array}{l}\text { Kalingpong-Phuntsholing-Chubuka Dzong-Paro-Ha (Sele La, } \\
\text { Hara Chu La)-Paro-Tremo La-Paro-Thimphu-Lingzhi Dzong- } \\
\text { Laya-Gasa-Punakha-Trongza-Thimphu-Buxa }\end{array}$ \\
\hline 1961 & June-August & $\begin{array}{l}\text { D. Doig } \\
\text { Journalist }\end{array}$ & $\begin{array}{l}\text { Rajabhat Khawa (India)-Phuntsholing-Chhukha Dzong-Paro- } \\
\text { Thimphu }\end{array}$ \\
\hline 1969 & October-December & $\begin{array}{l}\text { M. Matsuo } \\
\text { Civil Engineer }\end{array}$ & $\begin{array}{l}\text { Phuntsholing-Paro-Thimphu-Paro-Wangdue Phodrang- } \\
\text { Phunakha-Trongsa-Trashigang-Samdrup Jongkhar-(via India)- } \\
\text { Phuntsholing-Paro (Air) Kolkata }\end{array}$ \\
\hline
\end{tabular}


Figure 2. Road condition of Bhutan in 1969 [3].

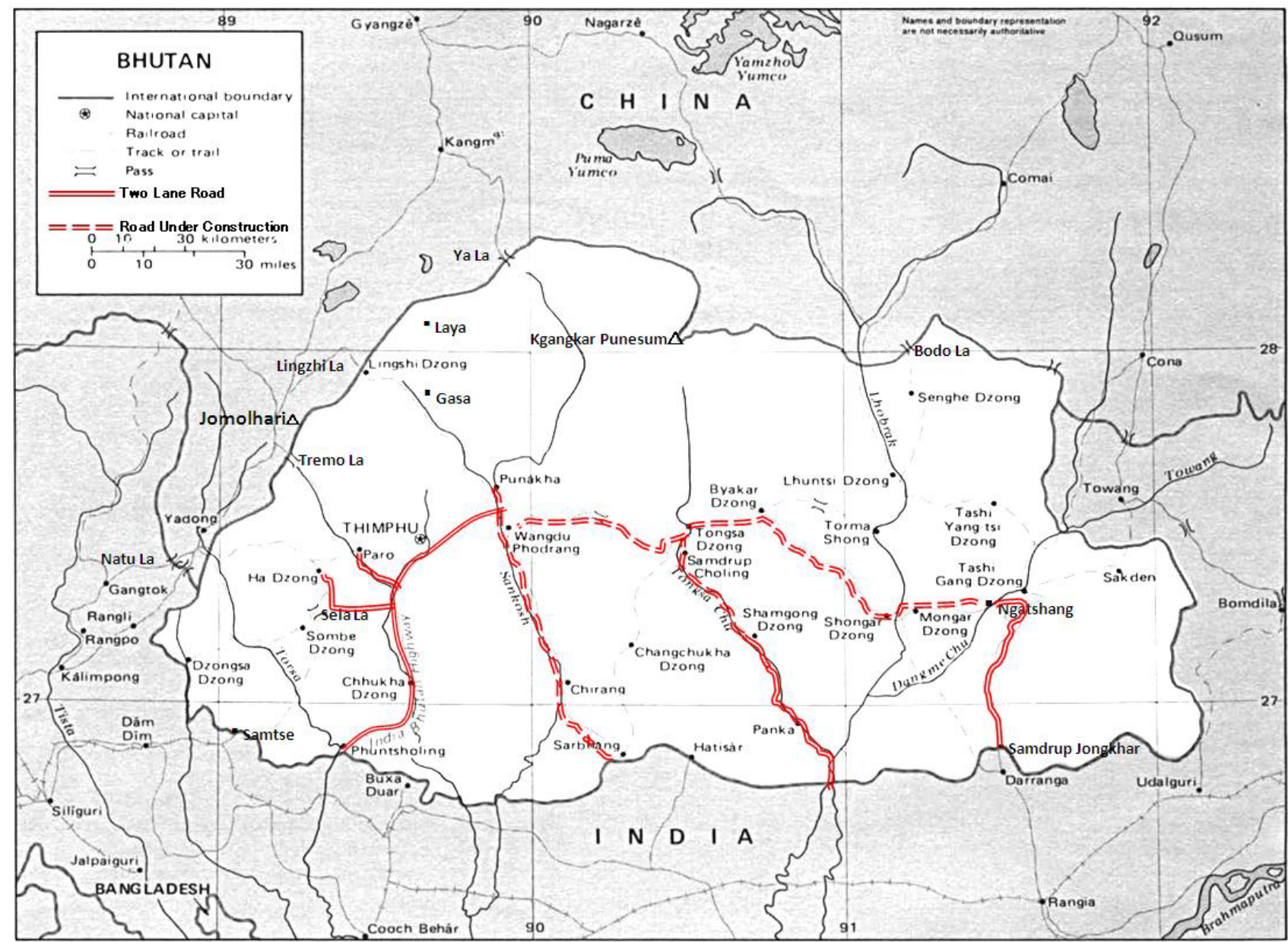

\subsection{J. C. White’s Mission in 1905-1907}

White's record of his mission, published in National Geographic [4], introduced the world to the existence of Bhutan. He visited Bhutan three times, in 1905, 1906, and 1907. Each time, he chose different passes by which to enter and exit. From his report [5], the passes and trails used by the Bhutanese and by Tibetan traders became clear. Tremo La, Lingzhi La, and Bodo La were three major passes into Tibet. On the other hand, his description of the southern routes is short and limited to mentioning problems of leeches, flies, and epidemics while travelling three routes.

\subsection{B. K. Todd's Visit in 1952}

A National Geographic magazine article on Bhutan was written by Todd [6]. He was invited as the first American visitor to the royal wedding of the third king, Jigme Dorji Wangchhuk, in 1952. He mentioned that passes from Tibet to Bhutan were already restricted. Therefore, instead of using the shortest routes through Tibet from Bhutan House, Kalingpong in Sikkim, he detoured all the way down to Samtse through India, then walked to Ha, struggling with leeches for 8 days in June. Six months later, he left Bhutan at Phuentsholing, farther away from Samtse. Similar to White's reports, Todd's description of these routes was brief and negative. 


\subsection{S. Nakao’s Visit in 1958}

Six years later, in 1958, S. Nakao [7], an ethnobotanist from Japan, was invited by Queen Kesang Choedon Wangchuck. Similar to Todd, Nakao first stayed at Bhutan House, and then he and his host, Prime Minister Jigme Dorji, departed for Phuentsholing using Indian rail. This Phuentsholing route is the route Todd used on his way back to Bhutan House. Nakao also struggled with leeches in June and traveled for 8 days to reach Paro. However, his record is not always negative. As a scientist, he documented the route conditions in more detail than White or Todd had. He wrote that there were bungalows to stay in each night, and houses were scattered along his way.

After arriving in Paro, Nakao spent 5 months intensively exploring Tremo La, near the areas Jomolhari, Lingzhi, Laya, and Sela La. He mentioned that at Tremo La, more than 100 mules passed each day. He had a keen eye and noted that Bhutanese passers-by were farmers selling extra rice in Tibet, whereas Tibetans were professional merchants. He was the last visitor who experienced this bustling trade because the border was closed in 1959.

When Nakao returned to Jigme Dorji's house in Ha from the plant-collecting trip in early August, he was informed that Indian Prime Minister Pandit Jawaharlal Nehru and his daughter Indira Gandhi's planned to visit Bhutan and follow Nakao's plant-hunting route. They visited in September and proposed the construction of a road between Phuentsholing and Paro. At that time, the third king, Jigme Dorji Wangchuck, was opposed to the road construction proposal [8].

\subsection{S. Doig's Visit in 1961}

Three years later, S. Doig [9] was the first British journalist to visit Bhutan from Phuentsholing. He wrote, "We broke our trip to Thimbu into six stages and stopped every 15 or 20 miles at typical Bhutanese resthouses.” These resthouses or bungalows have vanished with the trail now. He was with an Indian engineer commissioned to select a route for an automobile road. He explained by writing, "Early this year the King and Prime Minister of Bhutan visited New Delhi for talks with India's Prime Minister, Mr. Jawaharlal Nehru, and Indian government officials. Bhutan agreed to accept aid from India for a more extensive development program.” Doig further wrote, “A new road links Paro Dzong to Jainti, India, and allows the first vehicles to penetrate a land where the wheel has been virtually unknown for transportation.” Indeed, the road was constructed in 14 months and opened in 1962 [10]. The result was that, "Now an asphalt road coils 112 miles northward from the Indian border to span the 45-mile crow's-flight distance, reducing the journey to six hours by jeep [11].” A Japanese visitor, Ogata [12], mentioned that the postbus fare between Phuentsholing and Paro was 30 Rupees, while a jeep charged 200 Rupees in 1968. He added that a Bhutanese driving license cost 25 Rupees.

\subsection{Matsuo’s Mission Visit in 1969}

When Matsuo's party of six visited during October-December 1969, they left a detailed report on the east-west road that was under construction [8]. As a professor of civil engineering in Japan, Matsuo's observations of the road conditions were critical and precise. He wrote that the road was paved from Paro to Thimphu, but not to Wangdue Phodrang. 
In Wangdue Phodrang, his party hired seven mules and walked to Trongsa in 5 days. They occasionally came across road construction sites on their way to Trongsa, and Matsuo was concerned about road maintenance since the road was being constructed over fragile granite. On the other hand, he appreciated the gently laid out old mule tracks that were designed in harmony with nature. He also commented on wages and the other working condition of the workers who came from India and Nepal. After the party left Trongsa, there was no record of road construction until they reached Ngatshang, which was located 60 km west of Tashigang. From Ngatshang, Matsuo's party used a jeep and kept moving east to Tashigang. After staying there for several days, they traveled to Samdrup Jongkhar in a jeep supplied by the Indian army. After spending one night at an Indian military station in Samdrup Jongkhar, Matsuo returned to Phuentsholing in just 1 day, covering a distance of $450 \mathrm{~km}$ in India, and returned to Paro. His party was then permitted to board a special flight for royal families from Paro to Kolkata. Thus, the Matsuo party made a clockwise trip, staying in Phuentsholing twice and with the assistance of the Indian army.

In short, by 1969, two north-south routes had been constructed (Figure 2). Another route in the middle and the Wangdue Phodrang-Ngatshang part of the east-west route were under construction. The north-south highways overlapped traditional tracks, whereas the east-west roads often crisscrossed trails. Thus, roadless areas were rapidly reduced from the Indian side. Scofield [13], who made a round trip of the east-west highway by jeep even though it was not yet completed, explained the background of road construction in Bhutan, “Takeover of neighboring Tibet by China in the 1950s triggered Bhutan's decision to build an east-west road. Each family was providing four weeks' labor. When that failed, some 25,000 people were imported from Nepal paid under an Indian aid program.” The result was not only the creation of the east-west national highway as a backbone of the country, but also the inclusion of strong Indian influences from the south, as symbolized by the construction of three south-north roads (red lines of Figure 1). All of the northern border passes crossed by the White mission in the 1900s were officially closed; the Bhutanese were forced to turn south to exchange their rice for textiles or salt and use roads instead of trails.

\subsection{Tourism from 1974}

After the coronation of the fourth king, Jigme Singe Wangchuck, in 1972, Bhutan officially opened its doors to non-Indian foreign tourists. However, access was limited to ground transportation from Indian border towns until the official opening of the Paro airport in 1983 [14]. The first tourists, including eight Americans, five Spanish, and one Algerian, stayed for 1 week starting on October 3, 1974 [7]. In the same year, the creation of networks of protected area commenced, including the Jigme Dorji Wildlife Sanctuary [2].

Nakao revisited Bhutan in 1981, again arriving from Phuentsholing. First, he was delighted with the easy 6-hour drive to Paro, which made him appreciate the physically demanding 8-day walk in 1958 [15]. According to Ueda [16], Bhutan had 700 automobiles by the time of Nakao's second visit. Today, the proportion of foreign visitors that enter through Phuentsholing or Samdrup Jongkhar is limited. Seventy-six percent of tourists arrive in Paro by airplane [17]. Even if they want to trek from these border towns, no trails or bungalows remain. On the other hand, trails that are used for trading with Tibet, located on the north side of the east-west highway, remain and have been extended to 
allow travel within the border. The Snowman Trek is such a trail. Thus, trekkers can enjoy historic trading routes used by early visitors supported by camp staff and horsemen within the border of Bhutan. An American tour operator encouraged the government to limit tourism and to charge high fees [18]. This suggestion was adopted as a tariff system. The initial rate, which was implemented in 1982, was US \$130 per person per night's stay, even while trekking. Discounts for trekkers were introduced in 1994 and abolished again in 1997 [19]. One of the results was a sharp decrease in the proportion of trekking tourists, which declined from 36\% in 1996 to $4.3 \%$ in 2007 [20,21]. Later, a discounted tariff from the 11th day onward was introduced; the proportion of trekking is still quite low compared with that in Nepal.

\section{Trail-to-Road Transitions and Trailhead Conditions Based on Field Observations}

\subsection{Current Transportation Policy}

Bhutan has 3,636 kilometers of road network, and further road extension is proposed recognizing their environmental impacts [22]. "Bhutan 2020 [23]" mentions concerns on social impacts of road construction saying that some villages, located along mule tracks have been redundant when nearby roads have been constructed. However, its priority is put on transportation development as expressed as follows; “75\% of rural population live within half-day's walk from nearest road” by 2012 and then "an expanded system of feeder roads will have transformed the lives of many who have traditionally lived in isolation” by 2020 [23].

Recent government transportation policy [24] mentions such words as tunnels, electric tram/train, ropeways or cable car network, and helicopter operations. These transportation facilities are not only for residents but also for visitors.

\subsection{Trail to Road Relations}

The author visited Jigme Dorji National Park four times in the monsoon season. On his way to the park and back, he examined trail-to-road transitions and trailheads and made the following observations. On flat or gently-sloped lands, roads have replaced old trails without the addition of sidewalks. A cholten or stupa left over at the center (Figure 3) suggests that this used to be a typical trail (Figure 4).

Figure 3. Cholten on a road near Punakha.

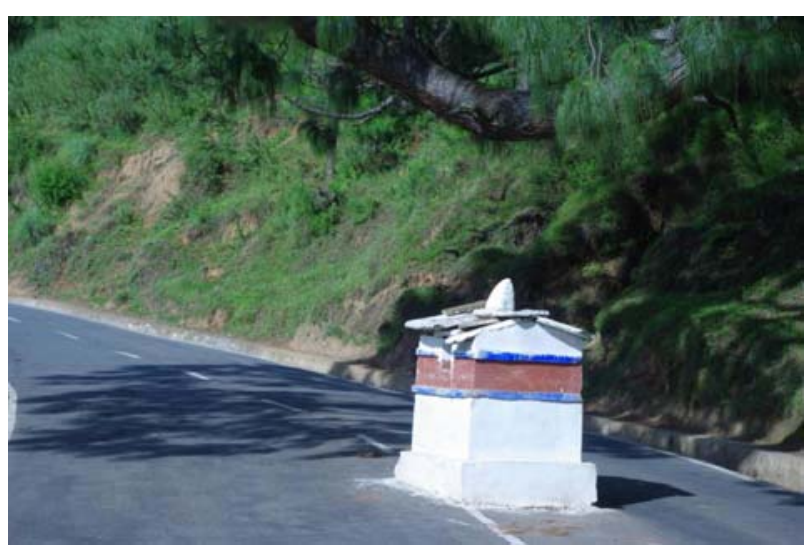


Figure 4. Trail with a Cholten near Thinlegang.

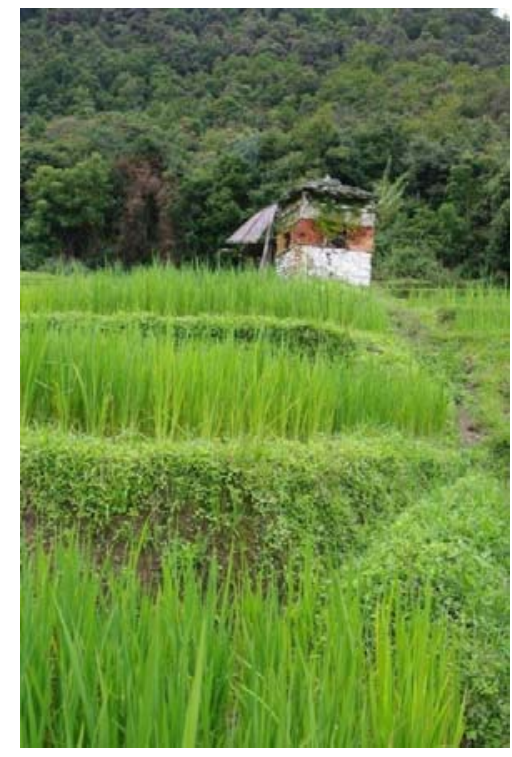

The south-north highways were often constructed over existing trails. The mountainous parts of the east-west highway did not replace old trails. As Matsuo observed in 1969, road construction was disconnected from trails, with intersections occurring at diverse intervals. Such left-over trails are still used by nearby residents to collect fuel wood and for other subsistence activities but are no longer used by mule-packing traders or trekkers (Figure 5). They are not designated as official trails and are not shown on tourist maps.

Figure 5. Cut-off trail near Dochu La.

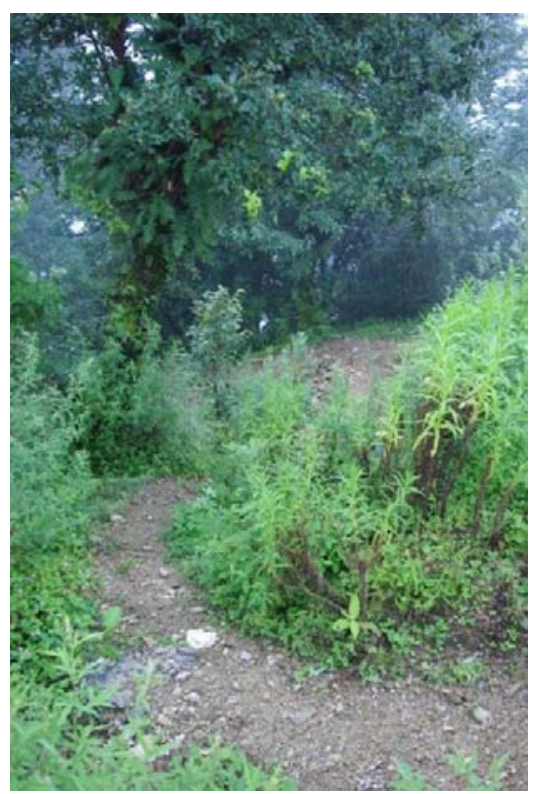

A popular temple of Chimi Lhakhang is located on a hillock near Lobesa, but there is no motorized access from the nearest community by road (Figure 6). To pray before the alter, all visitors have to walk for 20 min along a footpath between rice fields (Figure 7). The construction of such a short and flat road is easy, but the fourth king himself walked the path and discouraged such attempts, perhaps 
recognizing the religious value of the approach [25]. Monasteries in Bhutan are often located on steep cliffs. Monks and nuns never expect easy access, and their trails will be sustained.

Figure 6. Chimi Lhakhang on hillock, Lobesa.

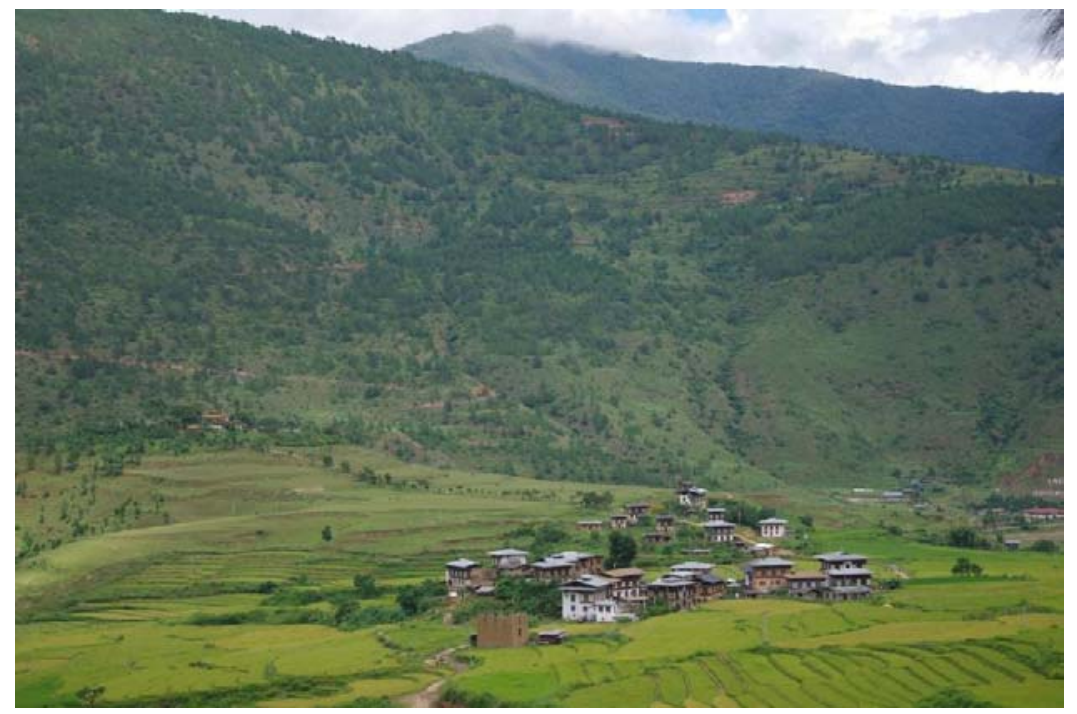

Figure 7. Trail to Chimi Lhakhang, Lobesa.

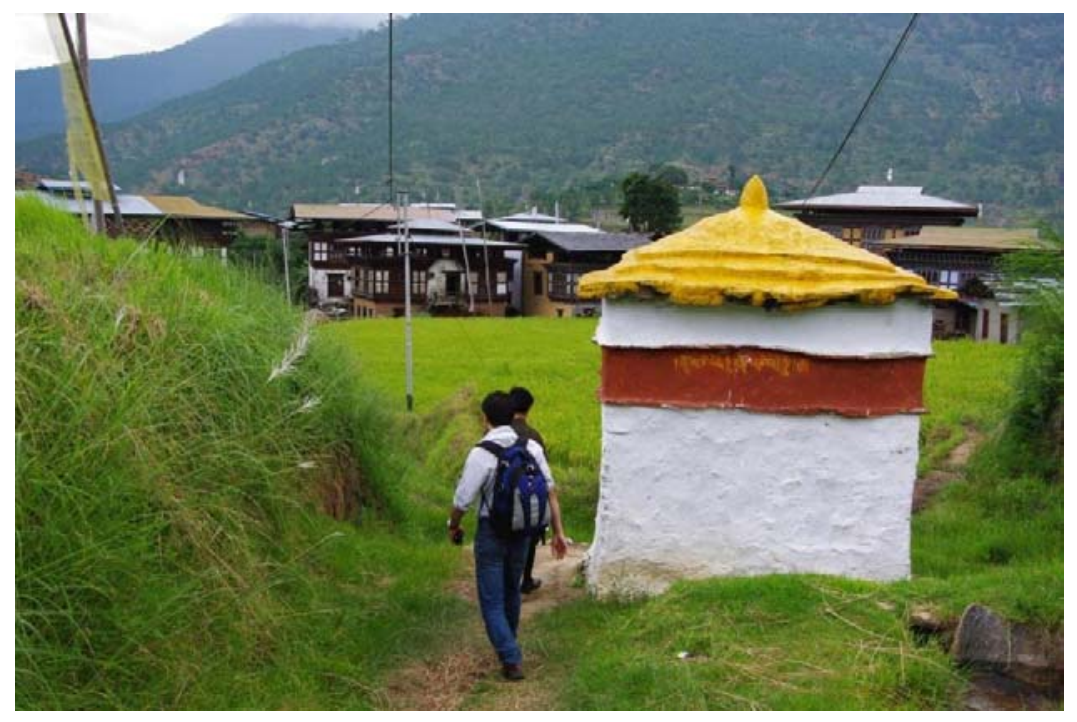

The fourth king also persuaded the residents of Bomdeling, located a 2-h walk away from Tashiyangste, not to construct a road [25]. This was not because of religious reasons but because of protection of Black-necked Cranes in the Bomdeling Wildlife Sanctuary (orange area of Figure 1).

\subsection{Trailheads of Jigme Dorji National Park}

Jigme Dorji National Park, renamed as a wildlife sanctuary in 1993 with accompanying boundary modifications, has three south-north trails connected to the Snowman Trek, which runs along the northern border (Figure 8 and yellow area of Figure 1). Until the official border closure in 1959, these trails were used by traders with Tibet as well as by yak herders making transhumance or seasonal migrations. The western part of the Jomolhari Trek from Drukgyel Dzong includes a stone-paved 
branch to Tremo La, whereas the eastern part, from Dodina, leads traders to Lingzhi La. The Laya-Gasa Trek is connected with Tibet through Tomo La and Wagya La near Masa Gang peak (Table 2).

Figure 8. Map of Jigme Dorji National Park [2].

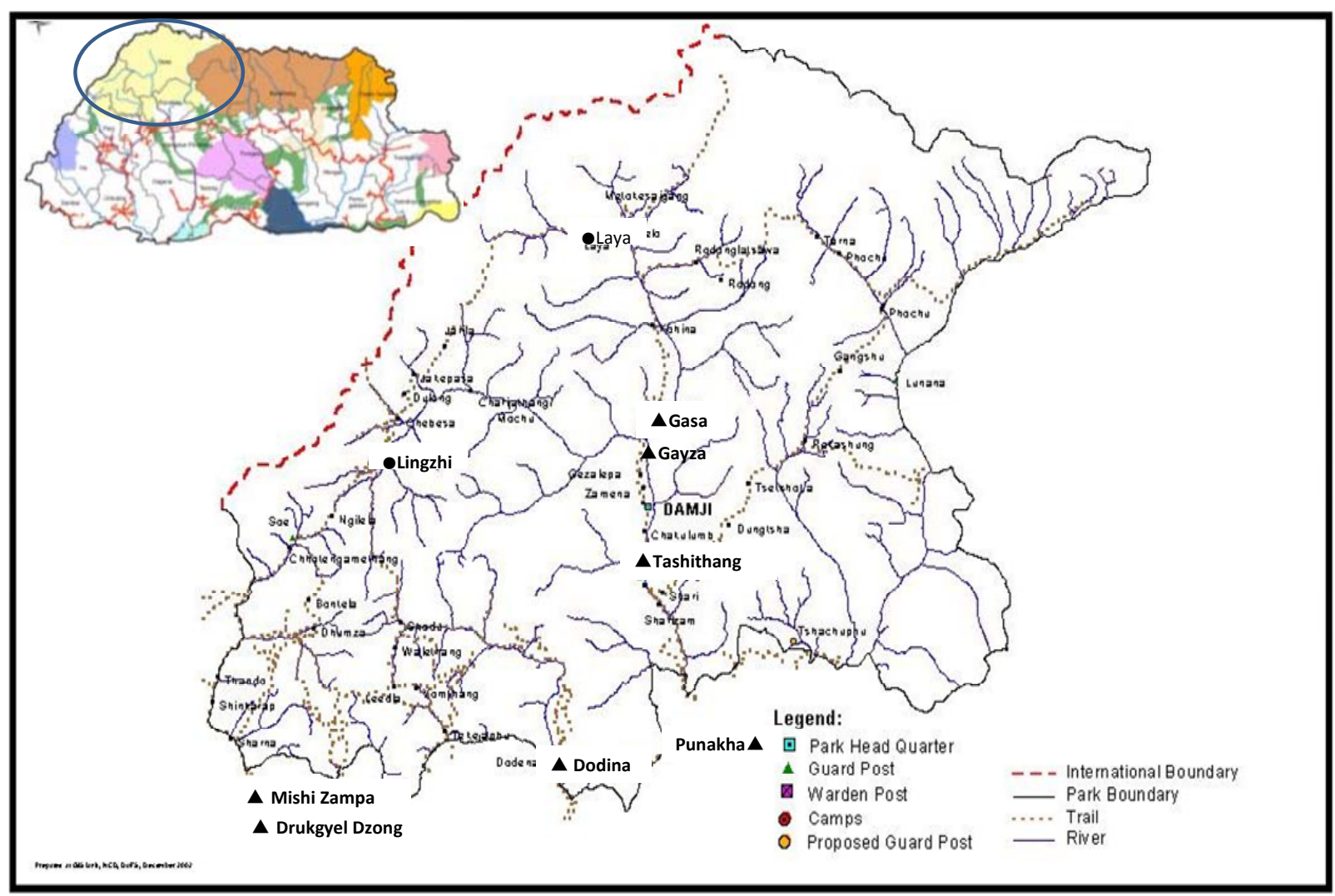

Table 2. Three trails and their trailheads in Jigme Dorji National Park.

\begin{tabular}{lllll}
\hline Trails & $\begin{array}{l}\text { Trailheads in } 1998 \text { (Distance } \\
\text { from Gateway Towns) }\end{array}$ & Trailheads in 2011 & $\begin{array}{l}\text { Trailheads-Park } \\
\text { Boundary Relations }\end{array}$ & $\begin{array}{l}\text { Passes to } \\
\text { Tibet }\end{array}$ \\
\hline $\begin{array}{l}\text { Jomolhari } \\
\text { Trek (West) }\end{array}$ & $\begin{array}{l}\text { Drukgyel Dzong (14 km from } \\
\text { Paro) }\end{array}$ & $\begin{array}{l}\text { Drukgyel Dzong /Mishi } \\
\text { Zampa with 4WD } \\
\text { Jomolhari }\end{array}$ & Outside the Park & Tremo La \\
$\begin{array}{l}\text { Trek (East) } \\
\text { Laya-Gasa } \\
\text { Trek }\end{array}$ & $\begin{array}{l}\text { Tashithang (25 km from } \\
\text { Punakha) }\end{array}$ & Gayza/Gasa & On the Boundary & Lingzhi La \\
\hline
\end{tabular}

The western part of the Jomolhari Trek is the most popular route in Jigme Dorji National Park. Its official trailhead is Drukgyel Dzong, but unpaved feeder road (Figure 9) stretches about $5 \mathrm{~km}$ to a suspension bridge over the Paro River at Mishi Zampa (Figure 10). Local taxis often come to this point. Furthermore, some trekkers prefer to use cars to reduce the number of hours walked on the first day [26]. This behavior by destination-oriented trekkers seems common [27]. If the road becomes paved, the trailhead will move to the bridge. However, if a new bridge for automobiles is constructed, it will move farther north as happening on Laya-Gasa Trek, further reducing the roadless area. In any case, trekkers will bypass the roadside communities to reach the new trailhead. 
Figure 9. Jomolhari Trek from Drukgyel Dzong.

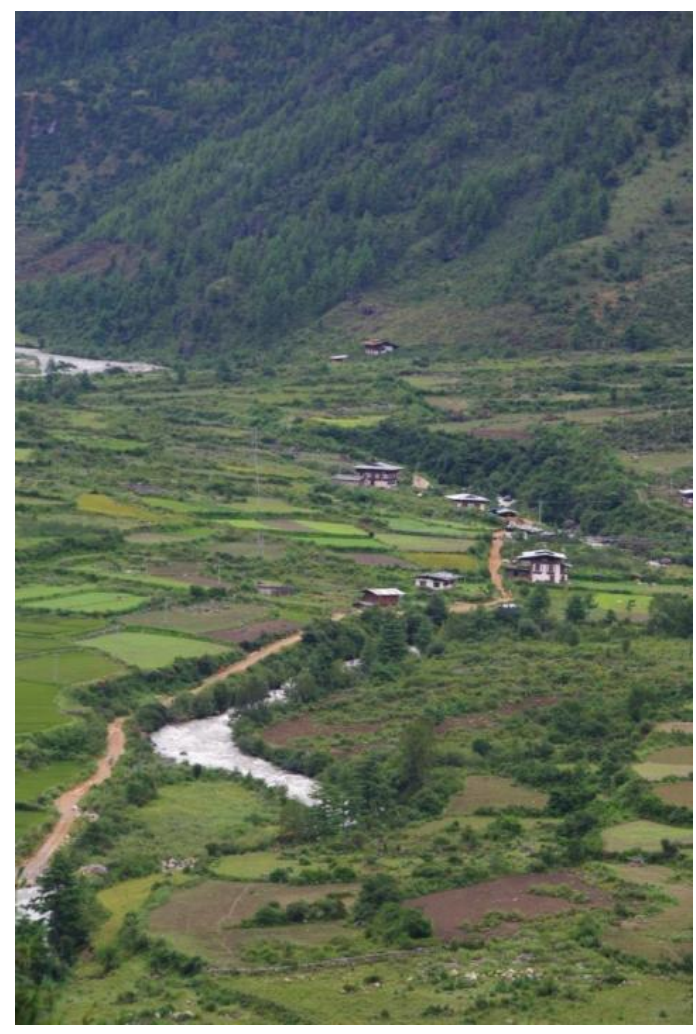

Figure 10. Suspension bridge at Mishi Zampa of Jomolhari Trek.

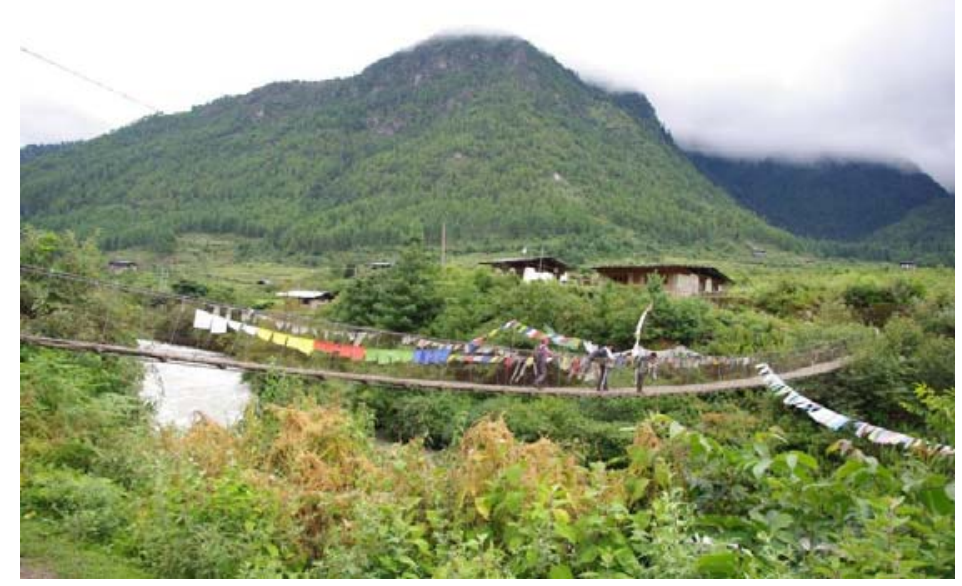

The official trailhead of the eastern part of the Jomolhari Trek is at Dodina, $15 \mathrm{~km}$ from Thimphu. This trail was used by the White mission to leave Bhutan in 1905. Nakao also walked to Lingzhi on this trail and then headed for Punakha through Laya and Gasa in 1958. Because local users of this trail are affiliated with the Tango Gonpa or monastery, further extension of this road is unlikely. Therefore, this trailhead seems stable, and the park boundary coincides with the trailhead.

The third trek, the Laya-Gasa Trek, has changed since it was walked by Nakao. Japanese TV crew also walked from Punakha to Gasa in 1993. However, following road construction, the trailhead has shifted toward Gasa every year. The first edition of Lonely Planet Bhutan [18] mentioned that the road from Punakha ended at a forestry office at Tashithang, where the district boundary is located. The 
fourth edition [26] mentioned that the trailhead was Damji, where the headquarters of Jigme Dorji National Park is located, but suggested that the road reached the suspension bridge beyond the Gayza community (Figure 11). However, the author observed that road construction beyond Damji would cause land slide problems (Figure 12). Indeed, severe rain fall in August 2010 cut off the road in several places. The district administrator of Gasa, Dasho Sonam Jigme, said, "Maintain the old mule track, so that people bypass the major roadblock," to restore the old trail as a temporary lifeline [28] because an alternative route would require a 1-week walk to the east-west highway. His proposal suggested that the old trail not be taken over by the road and that it was more sustainable. This is because yak herders and horsemen prefer to use trails if they are not directly replaced by paved roads.

Figure 11. Transitional trailhead at Gayza, 2009.

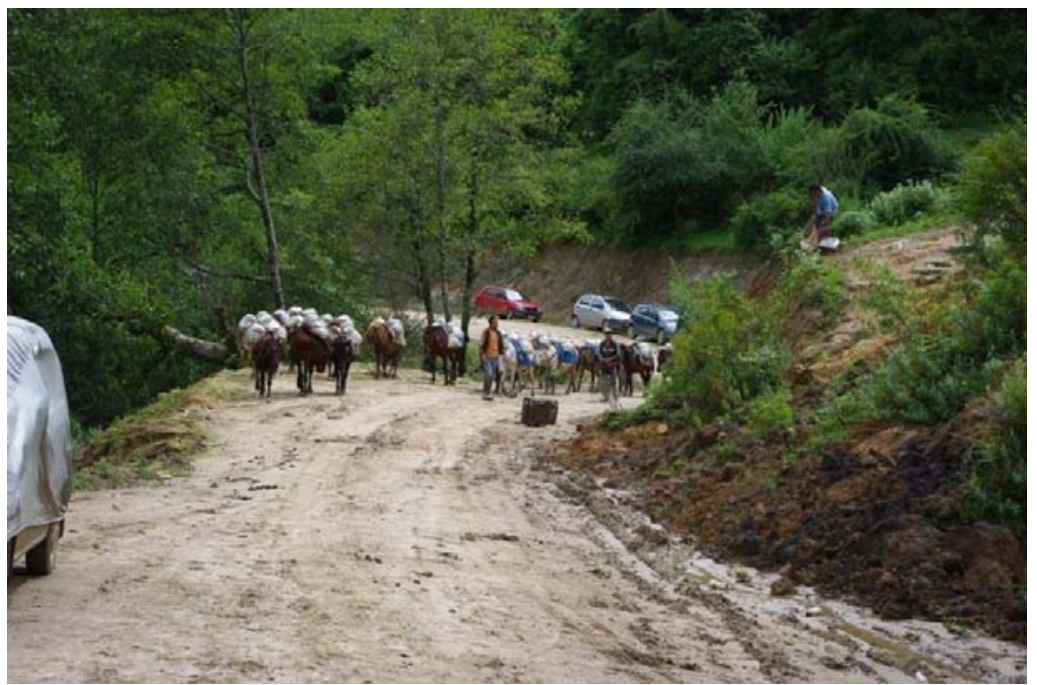

Figure 12. Road extended from Gayza.

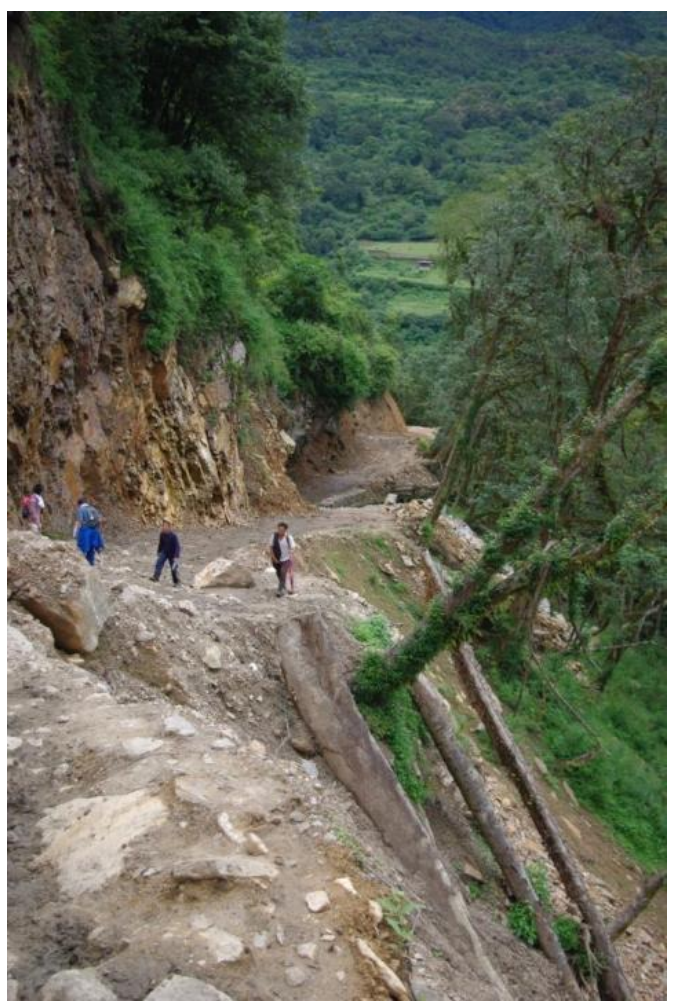




\section{Discussions for Coexistence of Trails with Roads}

\subsection{Sustainability of Inhabited Wilderness}

To control the extension of roads or to protect shrinking inhabited roadless areas, persuasive logic is necessary. Automobile access to Chimi Lhakhang was eliminated by identifying the precinct as a sanctuary. Religious significance has often been used to control mountain climbing. Religious sanctuaries can be construed as a form of protected area.

However, imposing wilderness conditions in protected areas with resident populations is difficult and cannot be justified [29,30]. The residents of Gasa would prefer the extension of the road to Gasa Dzong [31], and the management plan [2] states, “An additional extension of about $22 \mathrm{~km}$ from Damji to Gasa is expected to be completed in the next 3 years.” Indeed, the road was constructed near Gasa Dzong cutting off the old trail by August, 2011 (Figure 13). Park managers need persuasive framework to determine trailhead positions that both residents and trekkers understand since they have to preserve not only biodiversity but also cultural diversity as stipulated in Gross National Happiness policy [21].

Figure 13. Trail with Cholten cut off by new road near Gasa.

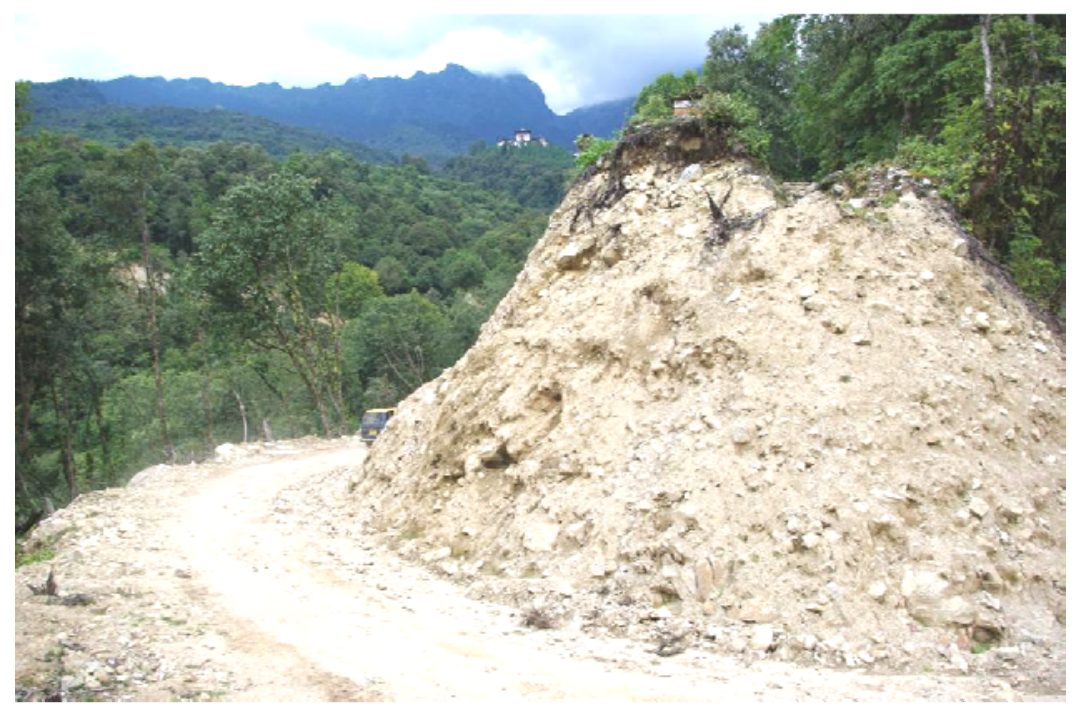

Benton MacKaye, a forester and regional planner in the Eastern United States, proposed using trails as a tool to control such mechanical civilization [32]. He proposed controlling metropolitan flow with dams and levees just like water control for flooding [33]. The dams are interpreted as filters for traffic control such as trailheads or gates, while the levees can be zones consisting of steep slopes or green belts to confine road influences. It is important to mention that MacKaye's idea developed from concerns about the rapid expansion of roads and automobiles in the United States after World War I. The situation resembles to that of Bhutan after 1962. MacKaye's dams and levees suggest the following two approaches with six options to control urban flow in protected areas of Bhutan (Figure 14). These approaches need to be employed together according to circumstances. 
Figure 14. Access options for trail sustainability.

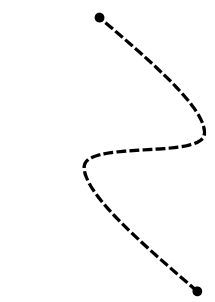

a) Original Trail

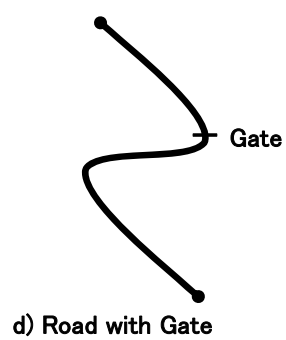

b) Short Trail with Trailhead

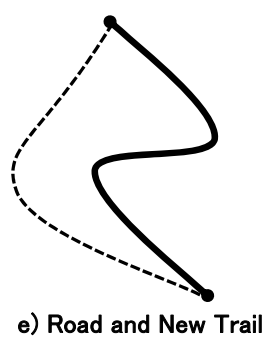

c) Widened Trail with Trailhead

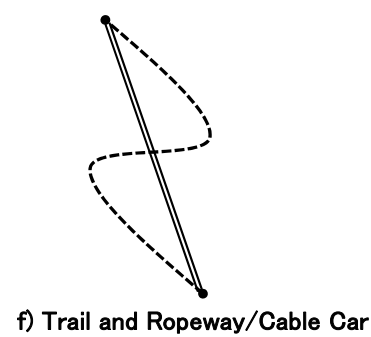

\subsection{Single Route with Trailhead as a Dam}

First, if residents in isolated roadless areas such as Laya prefer traditional life without auto access, impacts on the natural environment as well as on cultural heritage will be kept minimal (Figure 14(a)). Second, if they prefer 1-day walk instead of 2 days, the road is extended to a certain point such as Gasa (Figure 14(b)).

Third, if they prefer some improvement, a middle-path approaches taken by stock farmers in Alpine areas of Bavaria, Germany seems applicable to Bhutan. Ichida-Iwata [34] reports the consensus building process of roadless Almwirtshaft, or summer livestock farming in Alpine (Alm) zone of Bavaria. The local government supports Almwirtshaft not only based on ecological or on economic reasons, but also for cultural landscape and traditional environmental knowledge protection. The subsidy is used to maintenance of Alm huts, which are used both farmers and hikers, and transportation of such materials as faming tools by helicopter. Some Alms are located in roadless areas, and farmers take their livestock on foot and carry heavy equipments by helicopter. When the Alm farmers association appealed for the road construction or trail improvement, which hikers always stand against, the local government set the maximum width of 2.5 meters allowing only special vehicles like small tractors (Figure 14(c)). Such a moderate improvement of trails also sustains distinct cultural landscapes consisting of choltens and cantilever bridges (Figure 15) in Bhutan though the helicopter support will be limited by its cost and risk caused by topography or weather conditions.

Fourth, if the road is extended to the isolated communities, regulating traffic by gate is an option employed in Japan's protected areas [35]. The gate can be opened at a specific time of a day or a year to specific vehicles such as public buses or cars with permits (Figure 14(d)). This system requires gatekeepers, and their wages often supported by bus fares or parking fees. Such earnings can be used to subsidize horsemen to sustain their traditional environmental knowledge. 
Figure 15. Traditional bridge on Laya-Gasa Trek.

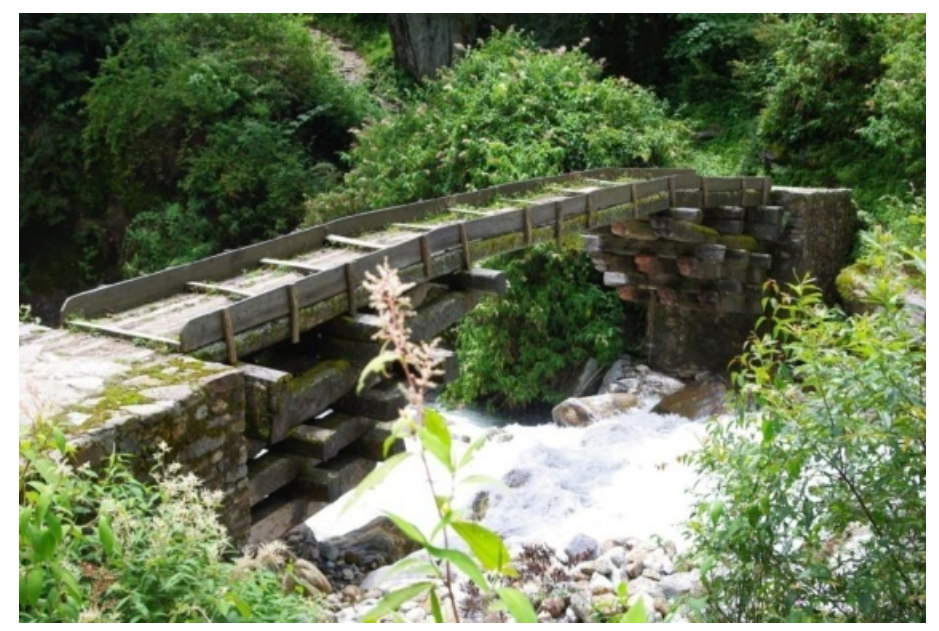

\subsection{Multiple Routes with Trail as Levee}

Both trails and roads are recognized as corridors in landscape ecology, but the former are environmental resource ones while the latter are disturbance ones [36]. Therefore, MacKaye's levees interpreted as environmental resource corridors go side by side with roads. In case, the trail is overtaken by a road as happened to those from the Indian border, new trails should be considered. Trails as levees have to be sufficiently separated from roads to absorb sound and sight of automobiles. This is what MacKaye demanded of planners of the Skyline Drives in the national parks of the Appalachian Mountains. Such trails can be used by horsemen or yak herders in Bhutan, too. If a certain number of trekkers use such trails, bungalows or rest houses, like those observed by Nakao and Doig, could be restored and managed by local communities [37].

If old trails are surviving along new road, horsemen or trekkers should be encouraged to use them. These trails not only function as environmental resources corridors including cultural heritages, but as emergency access routes as mentioned by the district governor of Gasa. In mountainous areas, roads are susceptible to natural disasters, and their restoration is time consuming.

If road construction has not started, alternative means of transportations such as ropeways, cableways or cogged railways should be considered (Figure 14(f)). These transportation modes do not depend on fossil fuels, and disturbance to the environment is less than roads as mentioned in the policy [24].

However, a case study of trail juxtaposed by ropeway tells that the majority of hikers prefer the latter even if the two-hour trail is full of alpine flowers [27]. Therefore, incentives to encourage trail use will be necessary. Traditionally, sacredness has been extended to forests surrounding shrines or temples in Japan, and all visitors are supposed to walk from the gate, which acts as a trailhead (Figure 16). However, Keishin-in temple, which can be reached by a 5-hour walk from the gate, installed an inconspicuous ropeway system (Figure 17) to carry commodities because its hospice accommodates hundreds of pilgrims every night. Tashira Ropeway on the Gangte Trek in Bhutan resembles the one at Keishin-in. This ropeway climbs 1,340 m to carry goods up to the village, but also carries people twice a day [26]. 
Figure 16. Trail for pilgrims to Keishin-in with stone monuments.

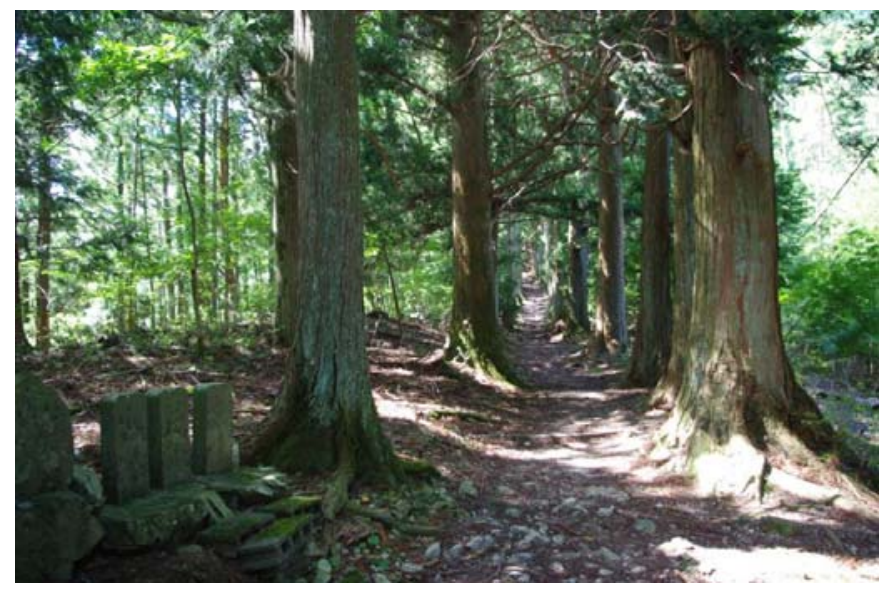

Figure 17. Gondola to carry goods to Keishin-in.

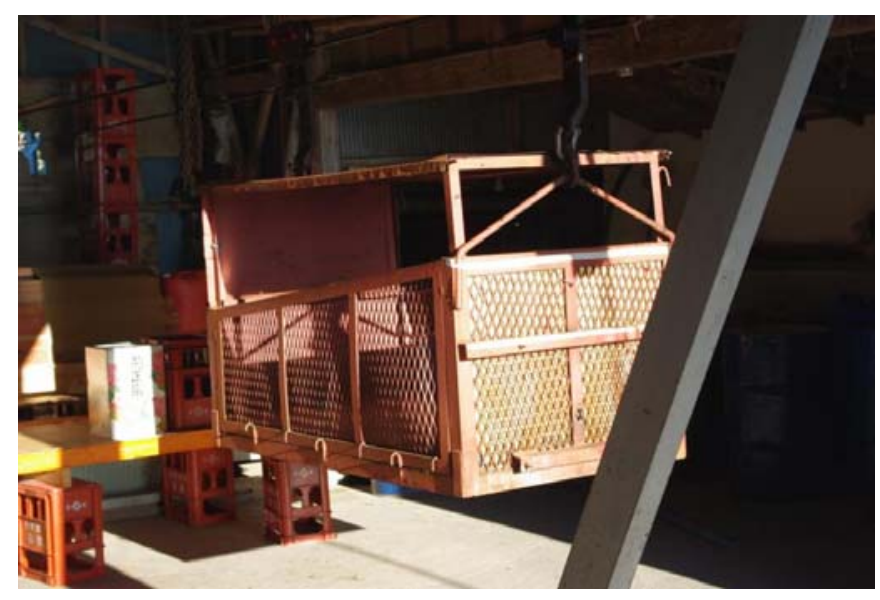

\section{Conclusions}

Until 1961, the southern border towns of Bhutan were trailheads for de-facto protected areas or inhabited wilderness [29]. Now, trailheads are moving farther north and have passed the boundaries of real protected areas. If the northern borders are opened, roads from Tibet will be constructed as also happened in Mustang, Nepal, with the creation of the Trans-Himalayan Highway [38]. This would result in further reduction and fragmentation of wilderness areas. Secure establishment of trailheads and the management or creation of trails is indispensable to maintain biodiversity and cultural diversity for residents as well as trekkers.

\section{Acknowledgments}

The author would like to express thanks to Dasho Sonam Jigme, Phuntsho Thinley and Kinley Tshering for their kind support of this research.

\section{Conflict of Interest}

The authors declare no conflict of interest. 


\section{References}

1. Wangchhuk, L. Fact about Bhutan, 2nd ed.; Absolute Bhutan Books: Thimphu, Bhutan, 2010.

2. Integrated Conservation Management Plan; Jigme Dorji National Park 2009-2012 Draft; Tshering, K., Ed.; Jigme Dorji National Park: Damji, Bhutan, 2009.

3. Bhutan. In Perry-Castañeda Library Map Collection; University of Texas at Austin: Austin, TX, USA, 1990. Available online: http://www.lib.utexas.edu/maps/middle_east_and_asia/bhutan.jpg (accessed on 26 October 2011).

4. White, J.C. Castles in the air. Natl. Geogr. 1914, 25, 365-453.

5. White, J.C. Sikkim and Bhutan, 1909; Reprinted by Kessinger Publishing: La Vergne, TN, USA, 2011.

6. Todd, B.K. Bhutan, land of the thunder dragon. Natl. Geogr. 1952, 102, 713-754.

7. Nakao, S. Unexplored Bhutan; Mainichi Shimbun: Tokyo, Japan, 1959; in Japanese.

8. Kuwabara, T.; Matsuo, M.; Kurita, Y.; Yoshino, H.; Tani, Y. Crossing Journey of Bhutan; Kodansha: Tokyo, Japan, 1978; in Japanese.

9. Doig, D. Bhutan, the mountain kingdom. Natl. Geogr. 1961, 120, 384-414.

10. Department of Roads, about Us; Ministry of Works \& Human Settlement: Thimphu, Bhutan, 2008. Available online: http://www.dor.gov.bt/Others/aboutus.htm (accessed on 5 July 2011).

11. Scofield, J. Bhutan crowns a new dragon king. Natl. Geogr. 1974, 133, 546-571.

12. Ogata, Z. A Rough Sketch of Bhutan; Fuyo Publishing: Tokyo, Japan, 1969; in Japanese.

13. Scofield, J. Life slowly changes in a remote Himalayan Kingdom. Natl. Geogr. 1976, 135, 658-683.

14. Brunet, S.; Bauer, J.; de Lacy, T.; Tshering, K. Tourism development in Bhutan: Tensions between tradition and modernity. J. Sustain. Tour. 2001, 9, 243-263.

15. Nakao, S. Exploring Natural History; Hokkaido University Press: Sapporo, Japan, 2004; Volume 3 , in Japanese.

16. Ueda, A. Concept of Development in Bhutan; Akashi Publisher: Tokyo, Japan, 2006; in Japanese.

17. International Tourism Monitor: Annual Report 2007; Department of Tourism: Thimphu, Bhutan, 2008.

18. Nadik, T.D. Tariff Change and Trends in Tourists Arrivals; Tourism Council of Bhutan: Thimphu, Bhutan, 2008.

19. Armington, S. Bhutan, 1st ed.; Lonely Planet: Victoria, Australia, 1998.

20. Rinzin, C.; Vermeulen, W.J.V.; Glasbergen, P. Ecotourism as a mechanism for sustainable development: The case of Bhutan. Environ. Sci. 2007, 4, 109-125.

21. Gurung, D.G.; Seeland, K. Ecotourism in Bhutan: Extending its benefits to rural communities. Ann. Tour. Res. 2008, 35, 489-508.

22. The Planning Commission Secretariat. Bhutan National Human Development Plan Report 2000; Royal Government of Bhutan: Thimphu, Bhutan, 2000.

23. Planning Commission. Bhutan 2020: A Vision for Peace, Prosperity and Happiness, Part II; Royal Government of Bhutan: Thimphu, Bhutan, 1999.

24. Economic Development Policy of the Kingdom of Bhutan; Royal Government of Bhutan: Thimphu, Bhutan, 2010. 
25. Imaeda, Y. Enchanted by Bhutan; Iwanami Shoten: Tokyo, Japan, 2008; in Japanese.

26. Mayhew, B. Bhutan, 4th ed.; Lonely Planet: Victoria, Australia, 2011.

27. Shiratori, K.; Ito, T. Motorized Access Control as a Wildland Recreation Management Tool: Access Changes and Visitor Behavior at Daisetsuzan National Park; Sievanen, T., Konijnendijk, C., Langner, L., Eds.; Forest and Social Services-the Role of Research, Finnish Forest Research Institute: Helsinki, Finland, 2001; Volume 815, pp. 29-41.

28. Kuensel. Remote Gets Remoter: Road Slip Brings a Host of Problems in the Northernmost District; Kuensel Corporation: Thimphu, Bhutan, 2010.

29. Catton, T. Inhabited Wilderness; University of New Mexico Press: Albuquerque, NM, USA, 1997.

30. Neumann, R.P. Imposing Wilderness; University of California Press: Berkeley, CA, USA, 1999.

31. Kato, G. Development of Trekking in Bhutan as a Form of Sustainable Tourism. M.S. Thesis, University of Tsukuba, Tsukuba, Japan, 2009; in Japanese.

32. MacKaye, B. An Appalachian trail: A project in regional planning. J. Am. Inst. Archit. 1921, 9, 325-330.

33. MacKaye, B. The new exploration: A philosophy of regional planning. The Appalachian Trail Conference and the University of Illinois Press: Harpers Ferry, WV, USA, 1990.

34. Ichida-Iwata, T. Agriculture, nature conservation and leisure in mountainous region: A case study in Bavaria. In Mountain Village Development and Environmental Conservation; Nansosha: Tokyo, Japan, 1997; pp. 272-290, in Japanese.

35. Daishima, K.; Ito, T. Automobile restriction in protected areas as a management tool. In Sustainable Management of Protected Areas for Future Generations; Jim, C.Y., Corlett, R.T., Eds.; IUCN: Gland, Swizerland and Friends of Contry Parks: Hong Kong, China, 2006; pp. 211-218.

36. Foreman, R.T.T.; Godron, M. Landscape Ecology; John Wiley \& Sons: New York, NY, USA, 1986.

37. Ito, T.; Kato, G. The role of hut system in promoting community-based tourism in Bhutan. Glob. Partnersh. 2010, 5, 1-12.

38. Mayhew, B.; Bindloss, J. Trekking in the Nepal Himalaya; Lonely Planet: Victoria, Australia, 2009.

(C) 2011 by the authors; licensee MDPI, Basel, Switzerland. This article is an open access article distributed under the terms and conditions of the Creative Commons Attribution license (http://creativecommons.org/licenses/by/3.0/). 